CLINICAL STUDY

\title{
Proinsulin levels in patients with pancreatic diabetes are associated with functional changes in insulin secretion rather than pancreatic $\beta$-cell area
}

\author{
Thomas G K Breuer ${ }^{1}$, Bjoern A Menge ${ }^{1}$, Matthias Banasch ${ }^{1}$, Waldemar Uhl $^{2}$, Andrea Tannapfel ${ }^{3}$, \\ Wolfgang E Schmidt ${ }^{1}$, Michael A Nauck ${ }^{4}$ and Juris J Meier ${ }^{1}$, \\ Departments of ${ }^{1}$ Medicine I and ${ }^{2}$ Surgery, St Josef-Hospital, Ruhr-University Bochum, Gudrunstrasse 56, 44791 Bochum, Germany, ${ }^{3}$ Department of \\ Pathology, Ruhr-University Bochum, 44789 Bochum, Germany and ${ }^{4}$ Diabeteszentrum Bad Lauterberg, 37431 Bad Lauterberg, Germany
}

(Correspondence should be addressed to J J Meier; Email: juris.meier@rub.de)

\begin{abstract}
Introduction: Hyperproinsulinaemia has been reported in patients with type 2 diabetes. It is unclear whether this is due to an intrinsic defect in $\beta$-cell function or secondary to the increased demand on the $\beta$-cells. We investigated whether hyperproinsulinaemia is also present in patients with secondary diabetes, and whether proinsulin levels are associated with impaired $\beta$-cell area or function.

Patients and methods: Thirty-three patients with and without diabetes secondary to pancreatic diseases were studied prior to pancreatic surgery. Intact and total proinsulin levels were compared with the pancreatic $\beta$-cell area and measures of insulin secretion and action.

Results: Fasting concentrations of total and intact proinsulin were similar in patients with normal, impaired (including two cases of impaired fasting glucose) and diabetic glucose tolerance $(P=0.58$ and $P=0.98$ respectively). There were no differences in the total proinsulin/insulin or intact proinsulin/insulin ratio between the groups $(P=0.23$ and $P=0.71$ respectively). There was a weak inverse association between the total proinsulin/insulin ratio and pancreatic $\beta$-cell area $\left(r^{2}=0.14\right.$, $P=0.032$ ), whereas the intact proinsulin/insulin ratio and the intact and total proinsulin levels were unrelated to $\beta$-cell area. However, a strong inverse relationship between homeostasis model assessment index of $\beta$-cell function and both the total and the intact proinsulin/insulin ratio was found $\left(r^{2}=0.55\right.$ and $r^{2}=0.48$ respectively). The association of insulin resistance (IR) with intact proinsulin was much weaker than the correlation with fasting insulin.

Conclusions: Hyperproinsulinaemia is associated with defects in insulin secretion rather than a reduction in $\beta$-cell area. The weak association between intact proinsulin and IR argues against the usefulness of this parameter in clinical practice.
\end{abstract}

European Journal of Endocrinology 163 551-558

\section{Introduction}

In health, glucose homoeostasis is primarily controlled by the secretion of insulin from pancreatic $\beta$-cells (1). About $80-90 \%$ of the total circulating insulin concentrations are derived from mature, biologically fully active, insulin (2). In addition, a small percentage of immature insulin precursors and incomplete proinsulin cleavage products, such as intact proinsulin, des (31,32)-proinsulin and des (64,65)-proinsulin, are being co-secreted along with mature insulin. While in healthy, non-diabetic subjects, these precursors constitute only a minor fraction of the total amount of secreted insulin, the release of proinsulin is significantly increased in patients with type 2 diabetes as well as in individuals with impaired glucose tolerance (IGT) (2-5). A couple of recent studies have also reported an increase in intact proinsulin levels in insulin-resistant individuals $(6,7)$, although this finding has not been confirmed by others $(8,9)$. Nevertheless, the determination of intact proinsulin as a marker for the diagnosis of insulin resistance (IR) has been widely advocated (10).

Two major hypotheses have been expounded to explain the hyperproinsulinaemia in type 2 diabetes: some investigators have speculated that the increased release of proinsulin in such patients might result from an intrinsic defect in proinsulin processing, leading to an increased release of immature insulin precursors and thus contributing to the impairment in $\beta$-cell function in type 2 diabetes (5). Alternatively, hyperproinsulinaemia may be caused by an increased secretory demand on the $\beta$-cells, leading to depletion of the 'readily releasable' insulin granule pool and mobilisation of insulin granules from the 'reserve pool', which is thought to contain greater amounts of immature insulin precursors (11). The latter explanation would 
be supported by the fact that the ratio of proinsulin over insulin was also increased in humans after a hemipancreatectomy (12).

In order to address the aetiology of increased proinsulin release in patients with type 2 diabetes, two studies have compared the proinsulin/insulin ratios after a transient inhibition of insulin secretion aiming to induce $\beta$-cell rest $(13,14)$. Both studies showed clear reductions in relative proinsulin secretion after somatostatin infusion, but only one study could demonstrate a full restoration of the proinsulin/insulin ratio to similar levels as found in non-diabetic individuals (13). Therefore, the underlying causes for the hyperproinsulinaemia in type 2 diabetes are still elusive. Furthermore, although some studies have demonstrated an association of proinsulin/insulin ratio with various measures of insulin secretion, its relationship with $\beta$-cell mass has not yet been examined. Thus, whether this association is due to a reduction in $\beta$-cell number or a functional impairment in insulin release remains to be elucidated.

An alternative way to address whether the hyperproinsulinaemia in patients with type 2 diabetes is due to an intrinsic defect in proinsulin processing or an increased demand on the $\beta$-cells is to determine proinsulin levels in patients with diabetes due to other aetiologies than type 2 diabetes. Furthermore, by comparing proinsulin concentrations with pancreatic $\beta$-cell area and various measures of insulin secretion, it should be possible to ascribe the development of hyperinsulinaemia to defects in either $\beta$-cell mass or the functional regulation of insulin secretion.

Therefore, in the present study, total and intact proinsulin concentrations as well as various established measures of insulin secretion were determined in patients with and without diabetes secondary to pancreatic disorders immediately prior to pancreatic resections, and the fractional $\beta$-cell area was determined in the resected pancreatic tissue. By these means, we addressed the following questions: i) Do patients with diabetes due to pancreatic disorders exhibit disproportionate hyperproinsulinaemia compared to non-diabetic individuals? ii) Are increased proinsulin levels in these patients associated with defects in pancreatic $\beta$-cell area or $\beta$-cell function? iii) Do intact proinsulin levels predict IR in lean patients with and without diabetes due to pancreatic disorders?

\section{Patients and methods}

\section{Study design}

Thirty-three patients undergoing pancreatic surgery for chronic pancreatitis, benign pancreatic adenomas or papillary tumours necessitating partial pancreatectomy were studied pre-operatively. A prolonged oral glucose tolerance test as well as determinations of total and intact proinsulin levels were carried out, and the fractional $\beta$-cell area of the resected pancreas was measured. The study protocol was approved by the ethics committee of the Ruhr-University Bochum (registration number 2528). All patients provided written informed consent prior to study enrolment.

\section{Patients}

A total of 33 patients (17 males and 16 females) undergoing pancreatic resections in the Department of Surgery, St Josef-Hospital, Ruhr-University Bochum, between the years 2004 and 2007 were included. Amongst those, 17 patients had been diagnosed with chronic pancreatitis, 13 underwent surgery for the removal of benign pancreatic adenomas and 3 patients underwent partial pancreatectomy because of tumours of the ampulla of Vater. The clinical diagnoses of chronic pancreatitis, pancreatic carcinoma, pancreatic adenoma or ampullary cancer were confirmed by an independent pathologist in all cases. Diabetes was previously known in six patients (treated with insulin in four cases, glimepiride in one case and diet in one case), whereas the other patients had no history of known diabetes. A detailed description of the patient characteristics has been previously provided (15).

\section{Experimental procedures}

The experiments were performed in the morning after an overnight fast with subjects in a supine position throughout the experiments as described (15). All other concomitant medication was withdrawn since the evening of the preceding day. The experiments were started by the ingestion of the oral glucose load $(75 \mathrm{~g}$ glucose in $300 \mathrm{ml}$ ) over $5 \mathrm{~min}$, and capillary and venous blood samples were drawn at $t=-5,0,15$, 30, 60, 90, 120, 150, 180, 210 and 240 min. Capillary blood samples $(\sim 100 \mu \mathrm{l}$ ) were added to $\mathrm{NaF}$ (Microvette CB 300; Sarstedt, Nümbrecht, Germany) for the immediate measurement of glucose. Venous blood was drawn into chilled tubes containing EDTA and aprotinin (Trasylol; $20000 \mathrm{KIU} / \mathrm{ml}, 200 \mu \mathrm{l}$ per $10 \mathrm{ml}$ blood; Bayer $\mathrm{AG}$ ) and kept on ice. After centrifugation at $4{ }^{\circ} \mathrm{C}$, plasma for hormone analyses was kept frozen at $-28{ }^{\circ} \mathrm{C}$.

\section{Measurements}

Glucose was measured as described (15) using a glucose oxidase method with a Glucose Analyser 2 (Beckman Instruments, Munich, Germany).

Insulin was measured as described (15) using an insulin microparticle enzyme immunoassay (IMx Insulin, Abbott Laboratories). Cross-reactivity with proinsulin was $<0.005 \%(16)$. 
C-peptide was measured as described (15) using an ELISA kit from DAKO Ltd, Cambrigshire, UK.

Total proinsulin concentrations were measured using an ELISA kit from DRG Instruments GmbH, Marburg, Germany. This assay measures intact human proinsulin and has $100 \%$ cross-reactivity with its major processed intermediates des (31,32)-proinsulin, and $81 \%$ crossreactivity with des $(64,65)$-proinsulin, but no crossreactivity with insulin and C-peptide.

Intact proinsulin was measured using a two-site sandwich ELISA from TECO Diagnostics, Anaheim, CA, USA (17). First, an aliquot of the patient sample is added to a microtitre plate coated with a MAB able to bind intact proinsulin, des (31,32)-proinsulin and split (32,33)-proinsulin, but not insulin, C-peptide and the other 'des' and 'split' forms. After incubation and washing of unbound antibodies, a second antibody specific for intact proinsulin, des (64,65)-proinsulin and split $(65,66)$-proinsulin, but without any affinity for insulin, C-peptide and the other 'des' and 'split' forms is added. The combination of these two MABs has the ability to detect exclusively intact human proinsulin.

\section{Pancreatic tissue processing}

The resected pancreatic tissue was fixed in formaldehyde and embedded in paraffin for subsequent analysis as previously described (15). Sequential $5 \mu \mathrm{m}$ sections were stained for insulin using a guinea pig antiinsulin antibody (DAKO \# A 0564; lot no. 00001500) at 1:400 dilution and an alkaline phosphatase/RED (DAKO Real Envision Detection System, \# K 5007 and \# K 5005; lot no. 00025382 and lot no. 00025812 respectively) detection system.

\section{Morphometric analysis}

For the determination of the fractional $\beta$-cell areas, the entire pancreatic sections stained for insulin were imaged using a Zeiss Axioplan microscope equipped with a motorised stage $100 \times$ magnification $(10 \times$ objective $)$. A tile image of the tissue section was generated using the 'Mosaix' tool of the software Axiovision, version 4.5 (Zeiss, Göttingen, Germany). The fractional areas of the pancreas stained positive for insulin were digitally quantified using a colour-based threshold using Zeiss Axiovision software as previously described (15).

\section{Calculations and statistical analysis}

The HOMA index of $\beta$-cell function was calculated as described (18). The Matsuda index of insulin sensitivity was calculated from the insulin and glucose concentrations during the oral glucose tolerance test as described (19). Furthermore, an oral disposition index (DIo) was calculated from the product of the incremental insulin secretion (change in insulin divided by the change in glucose from 0 to $\left.30 \mathrm{~min}\left(\Delta_{\mathrm{IO-30}} / \Delta_{\mathrm{GO}-30}\right)\right)$ and the insulin sensitivity (estimated as $1 /$ fasting insulin), as recently described (20).

Subject characteristics are reported as mean \pm s.D., and results are presented as mean \pm s.E.M. Comparisons of continuous variables were carried out by ANOVA, followed by Duncan's post hoc test using GraphPad Prism, version 4.0. Correlation analyses were carried out using linear or non-linear regression functions.

\section{Results}

\section{Differences between the patient groups}

Fasting glucose concentrations were $90.4 \pm 2.3 \mathrm{mg} / \mathrm{dl}$ $(5.01 \pm 0.13 \mathrm{mmol} / \mathrm{l})$ in individuals with normal glucose tolerance (NGT), $87.8 \pm 4.3 \mathrm{mg} / \mathrm{dl} \quad(4.87$ $\pm 0.24 \mathrm{mmol} / \mathrm{l})$ in patients with impaired fasting glucose (IFG) and/or IGT and $112.7 \pm 8.0 \mathrm{mg} / \mathrm{dl}(6.25$ $\pm 0.44 \mathrm{mmol} / \mathrm{l})$ in patients with diabetes $(P<0.01)$. The corresponding insulin levels were $35.0 \pm 5.1$, $36.0 \pm 7.4$ and $36.9 \pm 4.3 \mathrm{pmol} / \mathrm{l}$ respectively $(P=0.98)$. The insulin/glucose ratio as well as the C-peptide/glucose ratio $15 \mathrm{~min}$ after oral glucose ingestion was significantly reduced in patients with diabetes $(P<0.05)$. The DIo was significantly reduced in patients with type 2 diabetes $(0.017 \pm 0.006)$ compared with those with IFG/IGT $(0.093 \pm 0.013)$ and controls (0.072 $\pm 0.008 ; P<0.0001)$.

Fasting concentrations of total proinsulin were 8.0 $\pm 2.4 \mathrm{pmol} / \mathrm{l}$ in patients with NGT, $7.9 \pm 1.7 \mathrm{pmol} / \mathrm{l}$ in patients with IFG/IGT and $10.8 \pm 2.8 \mathrm{pmol} / \mathrm{l}$ in patients with overt diabetes $(P=0.58$; Fig. 1$)$. Fasting levels of
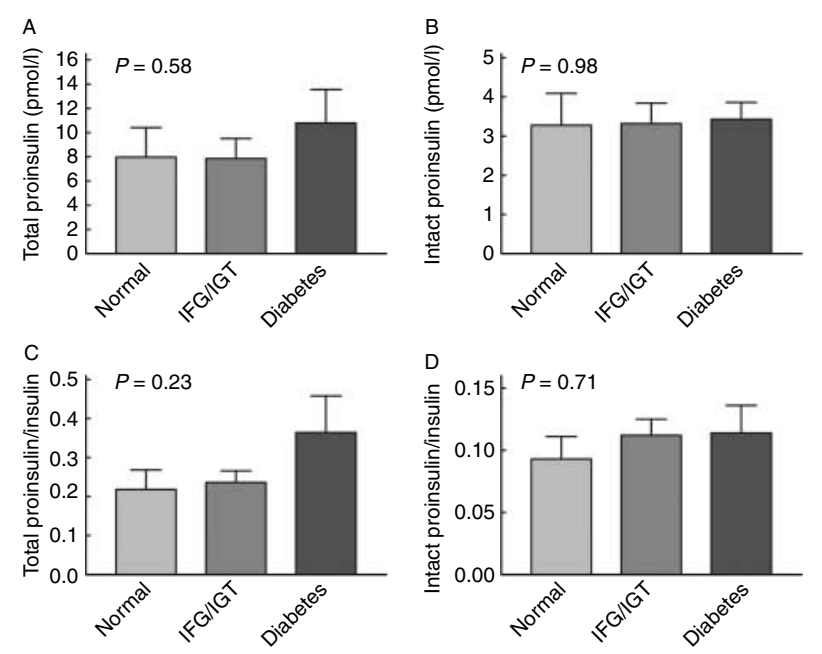

Figure 1 Plasma concentrations of total proinsulin $(A)$ and intact proinsulin (B) as well as the total proinsulin/insulin ratio (C) and the intact proinsulin/insulin ratio (D) in 8 individuals with normal glucose tolerance (NGT), 14 individuals with impaired fasting glucose (IFG) and/or impaired glucose tolerance (IGT), and 11 patients with diabetes. Data are presented as means \pm S.E.M. Statistics were carried out by ANOVA. 
intact proinsulin were $3.3 \pm 0.81,3.3 \pm 0.5$ and 3.4 $\pm 0.4 \mathrm{pmol} / \mathrm{l}$ respectively $(P=0.98)$. There were no differences in the ratio of total proinsulin/insulin $(P=0.23)$ or intact proinsulin/insulin $(P=0.71)$ between the groups. The ratio of intact proinsulin over total proinsulin was $0.46 \pm 0.03,0.50 \pm 0.05$ and $0.46 \pm 0.06$ in patients with NGT, IFG/IGT and diabetes respectively $(P=0.65)$.

\section{Relationship between proinsulin and $\beta$-cell area and function}

In order to address whether hyperproinsulinaemia is associated with a reduction in the number of pancreatic $\beta$-cells, linear regression analyses were performed. There was only a weak inverse association between the total proinsulin/insulin ratio and the fractional pancreatic $\beta$-cell area $\left(r^{2}=0.14, P=0.032\right)$, whereas the intact proinsulin/insulin ratio and the absolute fasting concentrations of both intact and total proinsulin were completely unrelated to $\beta$-cell area (Fig. 2). In a similar fashion, there was no significant association between the increment in insulin secretion after oral glucose ingestion $\left(\Delta_{\mathrm{IO}-30} / \Delta_{\mathrm{GO}-30}\right)$ or the DIo and the total and intact proinsulin levels or the proinsulin/insulin ratios (details not shown). However, a strong inverse relationship between the HOMA index of $\beta$-cell function and the total proinsulin/insulin ratio and the intact proinsulin/insulin ratio was found (Fig. 3).
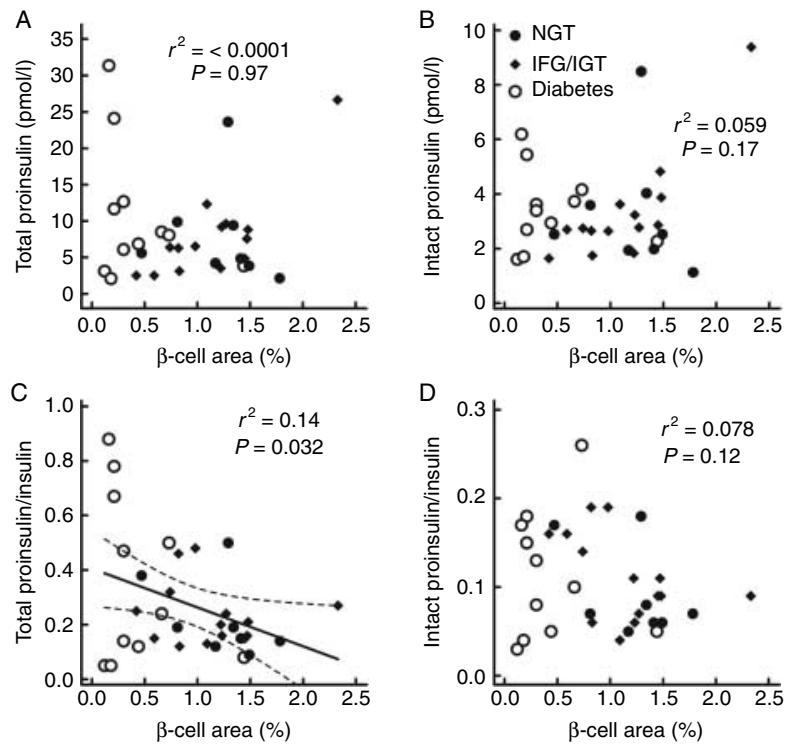

Figure 2 Correlation analyses between total proinsulin $(A)$ and intact proinsulin (B) as well as the total proinsulin/insulin ratio $(C)$ and the intact proinsulin/insulin ratio (D) and the pancreatic $\beta$-cell area in 8 individuals with normal glucose tolerance (NGT; filled circles), 14 individuals with impaired fasting glucose (IFG) and/or impaired glucose tolerance (IGT; filled diamonds), and 11 patients with diabetes (open circles). $r^{2}$ denotes the squared value of correlation coefficient. $P$ values were calculated by linear regression analysis.
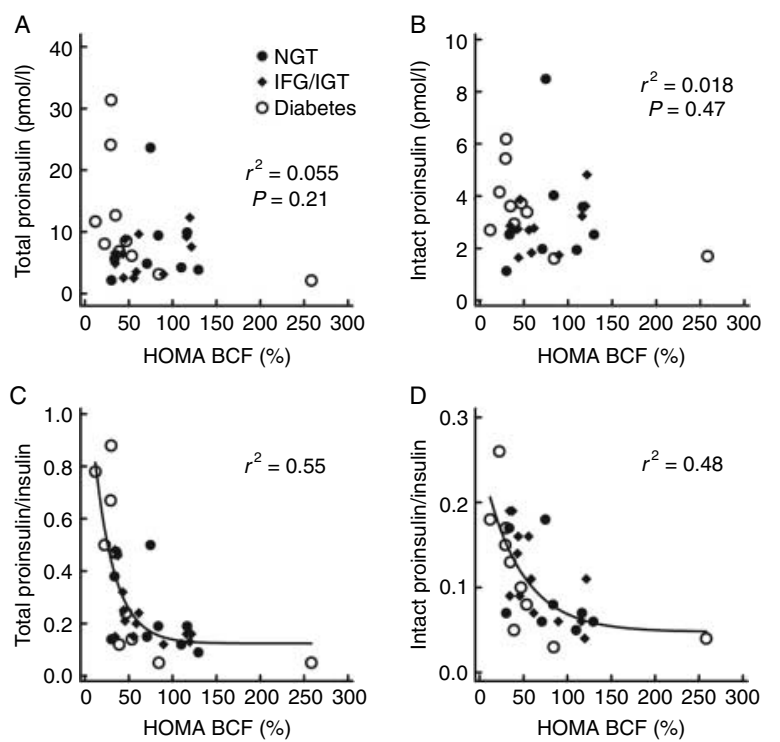

Figure 3 Correlation analyses between total proinsulin $(A)$ and intact proinsulin $(B)$ as well as the total proinsulin/insulin ratio $(C)$ and the intact proinsulin/insulin ratio (D) and the HOMA index of $\beta$-cell function in 8 individuals with normal glucose tolerance (NGT; filled circles), 14 individuals with impaired fasting glucose (IFG) and/or impaired glucose tolerance (IGT; filled diamonds), and 11 patients with diabetes (open circles). $r^{2}$ values and $P$ values in (A) and (B) were calculated by linear regression analysis. $r^{2}$ values in (C) and (D) were calculated by non-linear regression analysis.

\section{Relationship between proinsulin and IR}

HOMA index of IR was $1.32 \pm 0.2$ in normal glucosetolerant patients, $1.28 \pm 0.26$ in IFG/IGT patients and $1.71 \pm 0.25$ in patients with diabetes $(P=0.41)$. Likewise, the Matsuda index did not reveal significant differences in insulin sensitivity between the groups $(8.6 \pm 1.8,8.2 \pm 1.1$ and $6.8 \pm 0.9$ respectively, $P=0.56)$. There was an inverse linear association between the Matsuda index for insulin sensitivity and the total and intact proinsulin concentrations. In contrast, the ratio of intact proinsulin over insulin was positively related with the Matsuda index, suggesting a smaller percentage of intact proinsulin with increasing IR. Similar associations were found for the HOMA index of IR, although statistical significance was only reached for the association with total proinsulin concentrations as well as the ratio of intact proinsulin over insulin. In contrast, there was a tight association between the fasting insulin levels and both the HOMA index of IR and the Matsuda index $\left(r^{2}=0.71\right.$ and $r^{2}=0.65$ respectively, Figs 4 and 5).

The total proinsulin/insulin ratio increased with higher fasting glucose concentrations $\left(r^{2}=0.25\right.$, $P<0.01$ ), but there was no significant relationship between fasting glucose levels and the intact proinsulin/insulin ratio or the absolute concentrations of total or intact proinsulin (details not shown). 

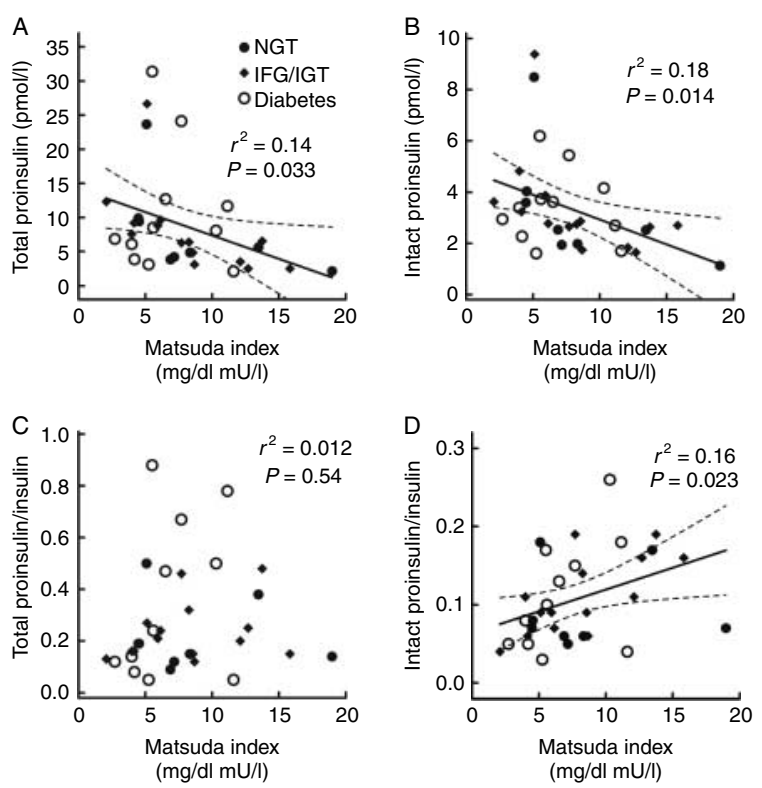

Figure 4 Correlation analyses between total proinsulin (A) and intact proinsulin (B) as well as the total proinsulin/insulin ratio (C) and the intact proinsulin/insulin ratio (D) and the Matsuda index of insulin sensitivity in 8 individuals with normal glucose tolerance (NGT; filled circles), 14 individuals with impaired fasting glucose (IFG) and/or impaired glucose tolerance (IGT; filled diamonds), and 11 patients with diabetes (open circles). $r^{2}$ values and $P$ values were calculated by linear regression analysis.

\section{Discussion}

A reduction in $\beta$-cell mass leading to insufficient insulin secretion has been increasingly recognised as an underlying cause of diabetes (21-26). Furthermore, increased concentrations of both total and intact proinsulin have been associated with impairments in insulin secretion and action $(2,5,7)$, but the relationship with pancreatic $\beta$-cell area has not yet been examined. The present study demonstrates that i) patients with diabetes secondary to pancreatic disorders are not characterised by either absolute or relative hyperproinsulinaemia, ii) increased proinsulin levels are associated with declining $\beta$-cell function, as measured by the HOMA index, rather than diminished pancreatic $\beta$-cell area and iii) there is only a weak positive association between IR and absolute proinsulin levels.

The patients included in this study differ from those examined previously with respect to proinsulin processing in many ways: in fact, most previous investigations in this area have been carried out in patients with type 2 diabetes, obese subjects as well as in individuals at high risk for type 2 diabetes (such as first-degree relatives) $(2-4,27)$. In contrast, the presently examined patients were characterised by pancreatic diseases necessitating pancreatic surgery. Furthermore, only 2 out of the 11 patients with overt diabetes studied herein had a first-degree relative with type 2 diabetes, and the mean
BMI of $24.1 \mathrm{~kg} / \mathrm{m}^{2}$ was much lower than typically found in patients with type 2 diabetes. Thus, the aetiology of hyperglycaemia in these patients is best described as 'pancreatic diabetes' (28), although the concomitant presence of type 2 diabetes cannot be fully ruled out due to the absence of clear diagnostic criteria. Therefore, it is important to bear in mind that the patients studied herein were rather heterogeneous regarding the aetiologies of hyperglycaemia, meaning that the results obtained are probably not representative of patients with type 2 diabetes.

A number of previous studies have reported elevated absolute proinsulin levels as well as disproportionate hyperproinsulinaemia in patients with type 2 diabetes $(3,29)$. Based on these findings, some authors have suggested a primary defect in proinsulin processing in the pathogenesis of type 2 diabetes (5). In contrast, the finding that a hemipancreatectomy also results in increased proinsulin levels in otherwise healthy humans has supported the alternative postulate that the hyperproinsulinaemia secondarily results from an increased secretory demand on the $\beta$-cells (12). The relatively normal proinsulin levels in this group of patients with diabetes secondary to pancreatic disorders tend to support the concept of a primary defect in proinsulin processing in the pathogenesis of type 2 diabetes. However, on a cautionary note, the fasting glucose concentrations in this group of diabetic patients were relatively low, meaning that the secretory demand on the $\beta$-cells might have still been too low to cause an increased release of proinsulin. In line with this, there was a significant association between fasting glycaemia and the total proinsulin/insulin ratio. Thus, even though this study might suggest differences with regards to proinsulin processing between patients with diabetes secondary to pancreatic disorders and patients with typical type 2 diabetes, it still emphasises the importance of hyperglycaemia in this process.
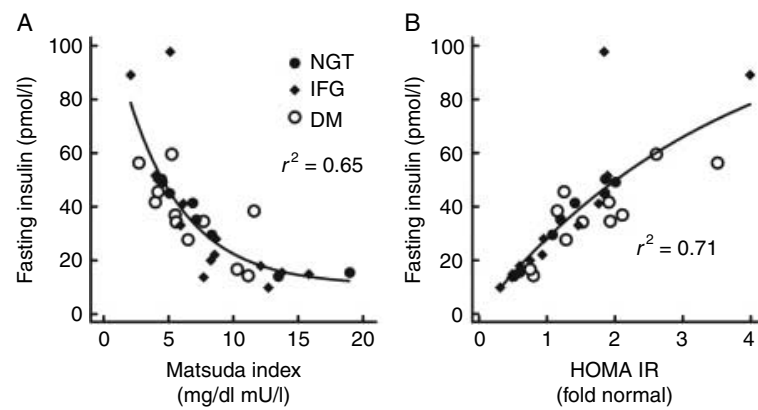

Figure 5 Correlation analyses between the fasting insulin concentrations and the Matsuda index of insulin sensitivity $(A)$ and the HOMA index of insulin resistance (B) in 8 individuals with normal glucose tolerance (NGT; filled circles), 14 individuals with impaired fasting glucose (IFG) and/or impaired glucose tolerance (IGT; filled diamonds), and 11 patients with diabetes (open circles). $r^{2}$ values were calculated by non-linear regression analysis. 
Although IR clearly increases the individual risk for the development of diabetes $(30,31)$, pancreatic $\beta$-cell mass has been increasingly recognised as an important mechanism for the development of diabetes (32). Biomarkers or, ideally, direct imaging tools for the determination of $\beta$-cell mass are therefore critically needed. We have previously demonstrated that various indices of insulin secretion (e.g. a C-peptide/glucose ratio after oral glucose ingestion) can predict pancreatic $\beta$-cell area to a reasonable extent (15). Because hyperproinsulinaemia has been reported in patients with type 2 diabetes, it was of interest to examine whether proinsulin levels or the proinsulin/insulin ratio would be related to the fractional $\beta$-cell area of the pancreas as well. However, although the association between the total proinsulin/insulin ratio with the pancreatic $\beta$-cell area was formally significant, the observed associations were generally weak and insufficient to allow for a valid prediction of $\beta$-cell mass based on circulating proinsulin levels. In contrast, the ratios of both total and intact proinsulin were inversely related to the HOMA index of $\beta$-cell function, suggesting an increased release of proinsulin with declining $\beta$-cell function. Thus, hyperproinsulinaemia seems to be associated with diminished $\beta$-cell function rather than a reduction in $\beta$-cell mass. This view is in line with the previous observation that the proinsulin/insulin ratio can be significantly improved after a short-term inhibition of insulin release using somatostatin $(13,14)$.

The present results may also give rise to reconsideration of the use of the proinsulin/insulin ratio as a surrogate marker of $\beta$-cell function and mass in clinical trials. Indeed, a relative reduction in proinsulin levels has been reported after both dietary (33) and pharmacological interventions with metformin (34), thiazolidinediones (35), DPP-4 inhibitors (36) and GLP-1 analogues (37), whereas sulphonylureas have been associated with an increased proinsulin release (38). The results of this study suggest that a lower proinsulin/insulin ratio may be indicative of an improvement in HOMA index of $\beta$-cell function, but its usefulness for the assessment of $\beta$-cell mass is likely to be negligible. Furthermore, it should be noted that the HOMA index of $\beta$-cell function only allows for some conclusions regarding the release of insulin in the fasting state, but has little predictive value for the overall capacity of insulin secretion upon glucose stimulation (39). In line with this, hyperproinsulinaemia in this study was also largely unrelated to the insulin secretory responses after oral glucose ingestion. Therefore, the assessment of the proinsulin/insulin ratio in clinical trials seems to offer limited additional value over the information gained from the determination of the HOMA index. Finally, it should be noted that both the proinsulin/insulin ratio and the HOMA index of $\beta$-cell function are likely to yield invalid estimates of $\beta$-cell function when determined during ongoing treatment with insulin secretagogues and without a prior drug washout.
A positive relationship between intact proinsulin levels and IR has been suggested in some, but not all, previous studies $(6,7,40)$. Consistent with this, the absolute concentrations of both total and intact proinsulin were positively associated with the HOMA index of IR and negatively related to the Matsuda index of insulin sensitivity. However, the relative ratio of intact proinsulin over insulin followed an even opposite relationship with insulin sensitivity, suggesting that the generally greater secretion of insulin rather than a disproportionate release of intact proinsulin was the driving force underlying this relationship. In agreement with this, the associations between fasting insulin levels and both the Matsuda index of insulin sensitivity and the HOMA index of IR were much closer than those observed for the proinsulin-based parameters. Thus, in this group of patients, the determination of intact proinsulin does not appear to be a meaningful predictor of IR. Instead, the simple measurement of fasting insulin concentrations might allow for a greater gain of information regarding the degree of insulin sensitivity.

In conclusion, in this group of lean patients with and without pancreatic diabetes, hyperproinsulinaemia was associated with functional defects in insulin secretion rather than a reduction in $\beta$-cell mass. The lack of disproportionate hyperproinsulinaemia in patients with diabetes secondary to pancreatic disorders might support the idea of an inherent defect in proinsulin processing in type 2 diabetes. Furthermore, the weak association between intact proinsulin and IR in these patients argues against the usefulness of this parameter for the clinical estimation of IR.

\section{Declaration of interest}

The authors declare that there is no conflict of interest that could be perceived as prejudicing the impartiality of the research reported.

\section{Funding}

These studies were supported by grants from the Deutsche Forschungsgemeinschaft (DFG grant no. Me2096/5-1 to J J Meier) and the Ruhr-University of Bochum (FoRUM grants to J J Meier).

\section{Acknowledgements}

The excellent technical assistance of Birgit Baller, Kirsten Mros, Heike Achner and Gudrun Müller is gratefully acknowledged.

\section{References}

1 Meier JJ \& Butler PC. Insulin secretion, In Endocrinology, 5th edn, pp 961-973. Eds LJ DeGroot \& JL Jameson. Philadelphia, PA: Elsevier Saunders, 2005.

2 Roder ME, Dinesen B, Hartling SG, Houssa P, Vestergaard H, Sodoyez-Goffaux $\mathrm{F} \&$ Binder $\mathrm{C}$. Intact proinsulin and $\beta$-cell function in lean and obese subjects with and without type 2 diabetes. Diabetes Care 199922 609-614. (doi:10.2337/diacare. 22.4.609) 
3 Roder ME, Porte D Jr, Schwartz RS \& Kahn SE. Disproportionately elevated proinsulin levels reflect the degree of impaired $\mathrm{B}$ cell secretory capacity in patients with noninsulin-dependent diabetes mellitus. Journal of Clinical Endocrinology and Metabolism $1998 \mathbf{8 3}$ 604-608. (doi:10.1210/jc.83.2.604)

4 Saad MF, Kahn SE, Nelson RG, Pettitt DJ, Knowler WC, Schwartz MW, Kowalyk S, Bennett PH \& Porte D Jr. Disproportionately elevated proinsulin in Pima Indians with noninsulin-dependent diabetes mellitus. Journal of Clinical Endocrinology and Metabolism 199070 1247-1253. (doi:10.1210/ jcem-70-5-1247)

5 Porte D Jr \& Kahn SE. Hyperproinsulinemia and amyloid in NIDDM. Clues to etiology of islet $\beta$-cell dysfunction? Diabetes 1989 38 1333-1336. (doi:10.2337/diabetes.38.11.1333)

6 Pfützner A, Standl E, Hohberg C, Konrad T, Strotmann HJ, Lübben G, Langenfeld MR, Schulze J \& Forst T. IRIS II study: intact proinsulin is confirmed as a highly specific indicator for insulin resistance in a large cross-sectional study design. Diabetes Technology and Therapeutics 20057 478-486. (doi:10.1089/dia. 2005.7.478)

7 Pfützner A, Kunt T, Hohberg C, Mondok A, Pahler S, Konrad T, Lübben $\mathrm{G} \&$ Forst T. Fasting intact proinsulin is a highly specific predictor of insulin resistance in type 2 diabetes. Diabetes Care 200427 682-687. (doi:10.2337/diacare.27.3.682)

8 Mykkanen L, Haffner SM, Hales CN, Ronnemaa T \& Laakso M. The relation of proinsulin, insulin, and proinsulin-to-insulin ratio to insulin sensitivity and acute insulin response in normoglycemic subjects. Diabetes 199746 1990-1995. (doi:10.2337/diabetes. 46.12.1990)

9 Mykkanen L, Zaccaro DJ, Hales CN, Festa A \& Haffner SM. The relation of proinsulin and insulin to insulin sensitivity and acute insulin response in subjects with newly diagnosed type II diabetes: the Insulin Resistance Atherosclerosis Study. Diabetologia 199942 1060-1066. (doi:10.1007/s001250051271)

10 Pfutzner A, Weber MM \& Forst T. A biomarker concept for assessment of insulin resistance, $\beta$-cell function and chronic systemic inflammation in type 2 diabetes mellitus. Clinical Laboratory $2008 \mathbf{5 4} 485-490$.

11 Leahy JL, Halban PA \& Weir GC. Relative hypersecretion of proinsulin in rat model of NIDDM. Diabetes $1991 \mathbf{4 0} 985-989$. (doi:10.2337/diabetes.40.8.985)

12 Seaquist ER, Kahn SE, Clark PM, Hales CN, Porte D Jr \& Robertson RP. Hyperproinsulinemia is associated with increased $\beta$ cell demand after hemipancreatectomy in humans. Journal of Clinical Investigation $1996 \quad 97$ 455-460. (doi:10. 1172/JCI118435)

13 Laedtke T, Kjems L, Porksen N, Schmitz O, Veldhuis J, Kao PC \& Butler PC. Overnight inhibition of insulin secretion restores pulsatility and proinsulin/insulin ratio in type 2 diabetes. American Journal of Physiology. Endocrinology and Metabolism 2000279 E520-E528.

14 Roder ME \& Kahn SE. Suppression of $\beta$-cell secretion by somatostatin does not fully reverse the disproportionate proinsulinemia of type 2 diabetes. Diabetes 200453 (Supplement 3) S22-S25. (doi:10.2337/diabetes.53.suppl_3.S22)

15 Meier JJ, Menge BA, Breuer TG, Muller CA, Tannapfel A, Uhl W, Schmidt WE \& Schrader H. Functional assessment of pancreatic $\beta$-cell area in humans. Diabetes 200958 1595-1603. (doi:10. 2337/db08-1611)

16 Stickle DF, Reynolds MA, Morris MD \& Quon MJ. Dynamic changes in plasma proinsulin/insulin ratio during insulin secretion influence correlation between radioimmunoassay (RIA) and IMX measurements of insulin. Clinica Chimica Acta 1999284 1-13. (doi:10.1016/S0009-8981(99)00072-8)

17 Pfutzner A, Pfutzner AH, Larbig M \& Forst T. Role of intact proinsulin in diagnosis and treatment of type 2 diabetes mellitus. Diabetes Technology and Therapeutics 20046 405-412. (doi:10. 1089/152091504774198124)

18 Matthews DR, Hosker JP, Rudenski AS, Naylor BA, Treacher DF \& Turner RC. Homeostasis model assessment: insulin resistance and $\beta$-cell function from fasting plasma glucose and insulin concentrations in man. Diabetologia $1985 \mathbf{2 8} 412-419$. (doi:10.1007/ BF00280883)

19 Matsuda M \& DeFronzo RA. Insulin sensitivity indices obtained from oral glucose tolerance testing. Diabetes Care 199922 1462-1470. (doi:10.2337/diacare.22.9.1462)

20 Utzschneider KM, Prigeon RL, Faulenbach MV, Tong J, Carr DB, Boyko EJ, Leonetti DL, McNeely MJ, Fujimoto WY \& Kahn SE. Oral disposition index predicts the development of future diabetes above and beyond fasting and 2-h glucose levels. Diabetes Care 200932 335-341. (doi:10.2337/dc08-1478)

21 Gepts W. Pathologic anatomy of the pancreas in juvenile diabetes mellitus. Diabetes 196514 619-633.

22 Meier JJ, Bhushan A, Butler AE, Rizza RA \& Butler PC. Sustained $\beta$ cell apoptosis in patients with long-standing type 1 diabetes: indirect evidence for islet regeneration? Diabetologia $2005 \mathbf{4 8}$ 2221-2228. (doi:10.1007/s00125-005-1949-2)

23 Clark A, Wells CA, Buley ID, Cruickshank JK, Vanhegan RI, Matthews DR, Cooper GJ, Holman RR \& Turner RC. Islet amyloid, increased A-cells, reduced B-cells and exocrine fibrosis: quantitative changes in the pancreas in type 2 diabetes. Diabetes Research 19889 151-159.

24 Klöppel G, Lohr M, Habich K, Oberholzer M \& Heitz PU. Islet pathology and the pathogenesis of type 1 and type 2 diabetes mellitus revisited. Survey and Synthesis of Pathology Research 1985 4 110-125. (doi:10.1159/000156969)

25 Butler AE, Janson J, Bonner-Weir S, Ritzel R, Rizza RA \& Butler PC. $\beta$-Cell deficit and increased $\beta$-cell apoptosis in humans with type 2 diabetes. Diabetes 200352 102-110. (doi:10.2337/diabetes.52. 1.102)

26 Schrader H, Menge BA, Schneider S, Belyaev O, Tannapfel A, Uhl W, Schmidt WE \& Meier JJ. Reduced pancreatic volume and $\beta$-cell area in patients with chronic pancreatitis. Gastroenterology 2009136 513-522. (doi:10.1053/j.gastro.2008.10.083)

27 Roder ME, Knip M, Hartling SG, Karjalainen J, Akerblom HK \& Binder C. Disproportionately elevated proinsulin levels precede the onset of insulin-dependent diabetes mellitus in siblings with low first phase insulin responses. The Childhood Diabetes in Finland Study Group. Journal of Clinical Endocrinology and Metabolism 1994 79 1570-1575. (doi:10.1210/jc.79.6.1570)

28 Sjoberg RJ \& Kidd GS. Pancreatic diabetes mellitus. Diabetes Care 198912 715-724. (doi:10.2337/diacare.12.10.715)

29 Kahn SE, Leonetti DL, Prigeon RL, Boyko EJ, Bergstrom RW \& Fujimoto WY. Proinsulin as a marker for the development of NIDDM in Japanese-American men. Diabetes 199544 173-179. (doi:10.2337/diabetes.44.2.173)

30 DeFronzo RA. The triumvirate: $\beta$-cell, muscle and liver. A collusion responsible for NIDDM. Diabetes 198837 667-687.

31 Reaven GM. Banting lecture 1988: role of insulin resistance in human disease. Diabetes 198837 1595-1607. (doi:10.2337/ diabetes.37.12.1595)

32 Meier JJ. $\beta$-Cell mass in diabetes: a realistic therapeutic target? Diabetologia 200851 703-713. (doi:10.1007/s00125-008-0936-9)

33 Davies MJ, Metcalfe J, Day JL, Grenfell A, Hales CN \& Gray IP. Improved $\beta$ cell function, with reduction in secretion of intact and $32 / 33$ split proinsulin, after dietary intervention in subjects with type 2 diabetes mellitus. Diabetic Medicine 199411 71-78. (doi:10.1111/j.1464-5491.1994.tb00233.x)

34 Nagi DK, Ali VM \& Yudkin JS. Effect of metformin on intact proinsulin and des 31,32 proinsulin concentrations in subjects with non-insulin-dependent (type 2) diabetes mellitus. Diabetic Medicine $1996 \quad 13$ 753-757. (doi:10.1002/(SICI)1096-9136 (199608)13:8<753::AID-DIA163> 3.0.CO;2-Z)

35 Smith SA, Porter LE, Biswas N \& Freed MI. Rosiglitazone, but not glyburide, reduces circulating proinsulin and the proinsulin:insulin ratio in type 2 diabetes. Journal of Clinical Endocrinology and Metabolism 2004 89 6048-6053. (doi:10.1210/jc.2004-0705)

36 Riche DM, East HE \& Riche KD. Impact of sitagliptin on markers of $\beta$-cell function: a meta-analysis. American Journal of the Medical Sciences 2009337 321-328. (doi:10.1097/MAJ. ob013e31818eb721) 
37 Buse JB, Rosenstock J, Sesti G, Schmidt WE, Montanya E, Brett JH, Zychma M, Blonde L \& for the LEAD-6 Study Group. Liraglutide once a day versus exenatide twice a day for type 2 diabetes: a 26-week randomised, parallel-group, multinational, open-label trial (LEAD-6). Lancet $2009 \mathbf{3 7 4}$ 39-47. (doi:10.1016/S01406736(09)60659-0)

38 Davies MJ, Metcalfe J, Day JL, Grenfell A, Hales CN \& Gray IP. Effect of sulphonylurea therapy on plasma insulin, intact and 32/33 split proinsulin in subjects with type 2 diabetes mellitus. Diabetic Medicine 199411 293-298. (doi:10.1111/j.1464-5491.1994. tb00274.x)

39 Festa A, Williams K, Hanley AJ \& Haffner SM. $\beta$-Cell dysfunction in subjects with impaired glucose tolerance and early type 2 diabetes: comparison of surrogate markers with first-phase insulin secretion from an intravenous glucose tolerance test. Diabetes $2008 \mathbf{5 7}$ 1638-1644. (doi:10.2337/db07-0954)

40 Kahn SE, McCulloch DK, Schwartz MW, Palmer JP \& Porte D Jr. Effect of insulin resistance and hyperglycemia on proinsulin release in a primate model of diabetes mellitus. Journal of Clinical Endocrinology and Metabolism 199274 192-197. (doi:10.1210/ jc.74.1.192)

Received 21 June 2010

Accepted 2 August 2010 